\title{
Transboundary water interaction III: contest and compliance
}

\author{
Mark Zeitoun ${ }^{1,2} \cdot$ Ana Elisa Cascão ${ }^{3}$ - Jeroen Warner ${ }^{4}$. \\ Naho Mirumachi ${ }^{5} \cdot$ Nathanial Matthews $^{6} \cdot$ Filippo Menga $^{7} \cdot$ \\ Rebecca Farnum ${ }^{5}$
}

Accepted: 29 April 2016/Published online: 11 May 2016

(C) The Author(s) 2016. This article is published with open access at Springerlink.com

\begin{abstract}
This paper serves international water conflict resolution efforts by examining the ways that states contest hegemonic transboundary water arrangements. The conceptual framework of dynamic transboundary water interaction that it presents integrates theories about change and counter-hegemony to ascertain coercive, leverage, and liberating mechanisms through which contest and transformation of an arrangement occur. While the mechanisms can be active through sociopolitical processes either of compliance or of contest of the arrangement, most transboundary water interaction is found to contain elements of both. The role of power asymmetry is interpreted through classification of intervention strategies that seek to either influence or challenge the arrangements. Coexisting contest and compliance serve to explain in part the stasis on the Jordan and Ganges rivers (where the non-hegemons have in effect consented to the arrangement), as well as the changes on the Tigris and Mekong rivers, and even more rapid changes on the Amu Darya and Nile rivers (where the non-hegemons have confronted power asymmetry through influence and challenge). The framework also stresses how transboundary water events that may appear isolated are more accurately read within the many sociopolitical processes and arrangements they are shaped by. By clarifying the typically murky dynamics of interstate relations over transboundary waters, furthermore, the framework exposes a new suite of entry points for hydro-diplomatic initiatives.
\end{abstract}

Mark Zeitoun

m.zeitoun@uea.ac.uk

School of International Development, University of East Anglia, Norwich, UK

2 UEA Water Security Research Centre, Norwich NR4 7TJ, UK

3 Stockholm International Water Institute, Stockholm, Sweden

4 Wageningen University, Wageningen, The Netherlands

5 Department of Geography, King's College London, London, UK

6 CGIAR Program on Water, Land and Ecosystems, Colombo, Sri Lanka

7 University of Manchester, Manchester, UK 
Keywords Transboundary water · Conflict and cooperation · Hegemony · Counter-hegemony · Hydro-hegemony

\section{Introduction}

Hydro-political research seeking to induce equitable transboundary water interaction is extensive in both breadth and depth (see, e.g. Frey 1993; Wolf 2002; McCaffrey 2007; Kehl 2011; Dinar et al. 2012; Schmeier et al. 2015). There is next to no effort spent on how change towards an equitable water arrangement actually comes about, however. The gap is a problem for hydro-diplomatic efforts which may have a destination in mind, but no sight of the obstacles - and opportunities - that lie along the path to get there. Pragmatic water conflict management initiatives that promote compliance with existing arrangements may thus be ineffective not simply for downplaying the root causes of tensions (see Zeitoun et al. 2014), but also for mismatching means and ends: a glance at the rapid changes in the once deeply entrenched water conflicts on the Nile and Amu Darya rivers suggests it is a result more of contest of the arrangements, than of compliance to them.

This article begins to fill the gap by exploring the way that states contest hegemonic transboundary water arrangements. It develops a conceptual frame that facilitates interpretation of the dynamic relationships that characterise these arrangements. The effort is intended to illuminate the path to water conflict resolution, which, as the first two articles in this series have argued, is best approached through an explicitly political angle that considers the influence of power asymmetry (see Zeitoun and Mirumachi 2008; Zeitoun et al. 2011).

The analysis builds from the growing body of hydro-political research referred to as 'critical transboundary water interaction analysis'. It thus acknowledges that transboundary water arrangements are (a) characterised by coexisting conflict and cooperation (see Mirumachi 2015); (b) influenced by useful forms of conflict, and, more significantly, destructive forms of cooperation (Zeitoun and Mirumachi 2008; Swatuk 2015); (c) shaped more by 'soft' forms of power than by 'hard' forms (Zeitoun et al. 2011); and (d) play out at numerous spatial and administrative levels (see, e.g. Warner 2005; Julien 2012; Norman 2012; Çonker 2014).

The dynamic frame of transboundary water interaction is built from inductive reasoning between two bodies of the literature and six cases. The groups of the literature are (1) research on compliance, contest, counter-hegemony, and counter-hydro-hegemony, and (2) theories about change in social orders. The utility of the frame is illustrated through its application to arrangements established along the Jordan, Tigris-Euphrates, Mekong, Ganges, Amu Darya, and the Nile, roughly from 1990 to 2015, and discussed in the light of the role that power plays in maintaining or changing the status quo. The paper concludes with thoughts on the limitations and insights of the approach.

\subsection{Clarifying assumptions: why 'the state', and what is 'contest'?}

Given the appreciation that transboundary water arrangements are influenced by events occurring within, below, and beyond the interstate level, the choice of the state as chief

\footnotetext{
1 The research stream has been pursued in International Environmental Agreements, notably through the papers Transboundary Water Interaction I (Zeitoun and Mirumachi 2008) and II (Zeitoun et al. 2011), and the 2012 special issue on Hegemony and asymmetry in transboundary river basins (Volume 12, Issue 3).
} 
object of study deserves some explanation. 'The state' here is understood to comprise all of its official organs, but primarily the elite cadre of decision-makers-namely heads of state, negotiators, and high-level members of water bureaucracies (or 'hydrocracies', in the words of Mollinga (2005)). Critical neo-Gramscian analysts should look outside the state, some would argue, at the manner by which transnational capital structures the international political economy (see Davidson-Harden et al. 2007; Selby 2007). The focus on the state is maintained here in part because of the significant role it plays in shaping the particular transboundary water arrangements that are under scrutiny. The state can impose dominant ideas and visions about water resources management, and the state-led institutions of river basin development can often be resistant to alterative views (Mirumachi 2015; Suhardiman et al. 2012). The objects traced in this paper are the transboundary water agreements, decisions and declarations made by 'the state', furthermore. Such decisions are most certainly influenced by forces in the international political economy, just as they are by culture, history, personal interests, and desires to satisfy other elements of the hydrocracies, or domestic constituencies, but they remain the state's decision. A greater concern with the focus on the state is the possible veiling of the most likely seeds and furrows of the very transformations examined, especially considering the extent to which counter-hegemonic actions and movements are driven by civil society (see, e.g. Loftus and Lumsden 2007; Karriem 2009; Domènech et al. 2013). While the bulk of the theory underpinning the conceptual frame is based on observations at various sub-national levels, deeper consideration of the influence of these actors in each case studied remains compromised by space.

It is also helpful for readers to have a clear understanding of the terms employed, prior to furthering the analysis. Compliance with a social order ${ }^{2}$ is understood to maintain or re-enforce it. If the order is hegemonic (in the Gramscian sense, that is, one that is maintained by a combination of force and agreement), its maintenance also relies upon the actors' consent to it. For the sake of transboundary water interaction analysis, the hegemonic order that is observed is understood to come about through multiple informal and sometimes formal institutions, and so is referred to as an established transboundary water arrangement. Contest of a hegemonic transboundary water arrangement occurs when the consent to the arrangement (or to the status quo) is broken, and so could lead to a change in the arrangement. The change can occur through uncoordinated counter-hegemonic tactics, which, if sufficiently aligned, may lead to counterhegemonic movements. If adequately organised, there may even be counter-hegemonic strategies. While the resultant change is not guaranteed, the breaks in consent are of particular interest, as actions that challenge hegemony allow sight of power structures that are normally concealed. Analysis of contestation of transboundary water arrangements should thus expose the ways in which both hard power and soft power are employed to derive new tactics, build up movements, and implement strategies. Power is understood to take on various practical and abstract forms, as Lukes' (2005 [1974]) three dimensions (coercive, bargaining, and ideational), and as elaborated upon in Zeitoun et al. (2011).

\section{Review of the literature on compliance and counter-hegemony}

When the great lord passes, the wise peasant bows deeply, and silently farts. Ethiopian proverb, in Lukes (2005 [1974]: 125).

\footnotetext{
${ }^{2}$ Henceforth 'order' is used to mean 'social order', and transboundary water arrangement ('arrangements') is the term used for such order at the international water level.
} 
This section reviews the literature on consent, compliance, and counter-hegemony. Conceptual work applying this theory to transboundary water issues is led by Cascão (2007, 2008, 2010b), who draws upon critical International Political Economy and International Relations work (e.g. Cox 1983; Scott 1985; Randall and Charlesworth 2000; Scott 2000; Tilly 2003). The body of work identifies three groups of mechanisms of resistance and of counter-hegemony available to non-hegemonic actors in transboundary basins and aquifers, each of which are discussed following.

Readers not familiar with this literature might consider, first, the distinction between resistance and counter-hegemony. As Fraser (1995) and Carroll (2006) point out, actions of resistance that simply affirm or improve one actor's entitlements or position within a social order hold little potential to transform that order. While it may thus contest the order, resistance is 'more reactive in [its] motivation, and refractory in consequence' (Persaud 2001: 7) than counter-hegemonic actions. By definition and in contrast, counter-hegemonic actions have the potential to transform an order, thereby bringing about radical changes to the way in which power is exercised by different actors.

\subsection{Mechanisms of resistance and of counter-hegemony [contest]}

Mechanisms of resistance and counter-hegemony covered here include coercive, leverage, and transformative. Coercive mechanisms of resistance and of counter-hegemony rely on compelling one actor involuntarily by the use or threat of force. Coercion may be effected by violence against, or sabotage of, elements of the order. A theoretical example is the destruction or construction of hydraulic infrastructure (in the case of transboundary waters), or simply the threat to do so. Leverage mechanisms of resistance and of counterhegemony resist or transform a hegemonic order through actions deriving from a rise in an actor's influence (based on Kotter 1985; Wagner 1988; Gargiulo 1993). This approach does not necessarily challenge the legitimacy of the order but works to win 'the game' within the rules that have been established. Leverage mechanisms at use in transboundary water settings include forming strategic alliances (whether with the opponent, or with other non-hegemonic actors) to improve bargaining power, launching hydro-diplomatic initiatives, using the principles of international law to contest existing legal frameworks and settings, or mobilising alternative sources of funding for large infrastructure projects.

Transformative mechanisms of counter-hegemony seek to transform a hegemonic order through the direct or indirect undermining of the legitimacy of the foundations that support it (see Rupert 1993; Bieler and Morton 2004; Worth and Kuhling 2004). By questioning widely accepted understandings of reality (i.e. 'common sense'), an alternative reality may be opened up through political agendas, discourses, and the construction of knowledge. To be effective, any alternative to the order would have to first strike into the consciousness of the intended recipients, thus allowing discursive and cerebral efforts for transformation to join alongside physical efforts. A transboundary water example is that of promoting a vision of resolution of a water conflict based on redistribution of the flows, if it defies deeply held views that the existing arrangement is so deeply entrenched that such redistribution could 'never' occur. Another example would be the reframing of a water conflict as tension over livelihoods, identities, or conceptions of governance, if the prevailing discourse frames it instead as one of the water resources. The act of reframing provides conflict resolution efforts a different emphasis, and broader set of potential solutions to consider. The end result of the use of transformative mechanisms may be a new transboundary water arrangement that could affect the everyday practices of water resources use, and the international political economy surrounding the basin. The outcomes are not 
predetermined or readily predictable: this arrangement could very much or not at all resemble its predecessor.

\subsection{Mechanisms to produce compliance [consent]}

Any social order that is hegemonic must by definition be continually reproduced. As such, the mechanisms of contest should be considered alongside the mechanisms used to produce compliance identified by Lustick ${ }^{3}$ (2002: 25). These are sketched out briefly following, exemplified with mechanisms that states might use to perpetuate transboundary water arrangements, thus preserving consent or to alter arrangements, thus breaking consent.

As with the 'coercive mechanism of resistance', compliance with the order can be assured through pressure created by the threat or use of force, e.g. the unilateral construction of infrastructure. Material capacities to create and gain access to alternatives (e.g. through more infrastructure or financial resources) can also create pressure on the weaker side to consent, without any direct, discernible, or even explicitly intentional exercise of power (see Allan and Mirumachi 2010; Mirumachi 2015). These types of mechanisms are thus referred to as coercive compliance-producing mechanisms. Utilitarian complianceproducing mechanisms are the 'carrots' to the 'stick' of coercive mechanisms. These can include inducements or rewards, such as political pay-offs (e.g. recognition and alliances for legitimacy-challenged regimes) or financial rewards (e.g. a share of the capital generated by a transboundary water project).

Normative compliance-producing mechanisms rely on instilling the belief that compliance with the order is right or a duty, even an obligation. The normative basis for this type of compliance is the legitimacy of the order, such that compliance is assured 'regardless of whether fear of punishment for refusal to comply is present, and regardless of calculations that may be made about the balance of costs and benefits entailed in compliance' (Lustick 2002: 23). Transboundary water treaties, 'best practice' of transboundary water management, and the operational procedures of international financial institutions that invest in transboundary water projects are examples of such mechanisms active in transboundary water arrangements. Global water conferences, such as the World Water Forums or Congresses, socialise water professionals and 'organic water intellectuals' into understandings and discourses that become common internationally (Warner 2011a; Newton 2014). Ideological hegemonic compliance-producing mechanisms go a step further, gaining an unquestioned acceptance of the order independent of the sense of obligation or any rewards or pressure on offer. When these mechanisms are effective, noncompliance with the order is unconsciously ruled out; consent can be counted on. An example of the effect of such mechanisms is the predictable and unconsidered reactions invoked when political issues such as the potential redistribution of transboundary waters are portrayed as national security issues ['securitization' (see Stetter et al. 2011)], as are the unquestioned facts about water derived from the construction of knowledge and sanctioned discourse (see, e.g. Molle 2008).

\subsection{Distinguishing between 'apparent' or 'veiled' consent and contest}

If there is no struggle, there is no progress.

-Frederick Douglass

\footnotetext{
3 And employed in Zeitoun and Warner (2006); see also Warner's (2011b: 22) 'ladder of compliance'.
} 
It would be simplistic, of course, to suggest that aspects of any complex political processinterstate transboundary water interaction not least of which-could be categorised neatly into mechanisms of compliance, resistance, and counter-hegemony. Just as conflict and cooperation coexist, hegemony and counter-hegemony are a 'dialectic pair', and both are shaped by any acts of contest or compliance by those involved (Cox 1983). This dialectic is elaborated in Shamir (2005), who argues that as hegemonic projects propagate (neoliberal political economic forces active in processes of globalisation, in his case), they necessarily induce the conditions under which counter-hegemonic forces, organisations and movements germinate, and flourish.

Distinguishing between the compliance with hegemony and the contest of hegemony is thus an important, yet tricky, task; each can resemble the other. A state is complying with arrangement when it collaborates with others on a transboundary water initiative to further its own interests, for example—what Daoudy (2007) refers to as 'strategic interaction'. Furthermore, the consent to a hegemonic arrangement may be given in degrees-from unconscious acceptance to open promotion of the arrangement by those who have wholly internalised the values (refer to Scott 2001; Lukes 2005). As Cascão (2008) argues, a nonhegemonic actor's resignation to an outcome that appears inevitable may thus be read as 'apparent consent', but this could lead to strategic collaboration — and so, in theory, to open contest of the order. Her exemplification-'Ethiopia has, in the past, signalled apparent consent, which has in practice been veiled contest in the Nile Basin hegemonic configuration' (Cascão 2008: 14)—is returned to later.

Breaking the consent to an existing hegemonic order is thus a crucial step in any contest of a transboundary water arrangement, regardless of the type of compliance-producing mechanism that the consent results from, and also whether that consent is open, apparent, or strategic. If the consent is only 'apparent', there may be no strategic reason for the party that seeks to transform the order to break it. The consent may even be tacit; that is, it may be more in effect than it is claimed to be. In this sense, verbal claims of resistance to an established order may be the start of a campaign of resistance, or of a counter-hegemonic movement. If the claims are not followed by the effort required to change the order, however, they may remain simply expressions of disagreement with that order, and in effect demonstrate tacit consent to it. This applies equally to individuals (who may believe their criticism of a hegemonic order challenges rather than re-enforces it, despite no accompanying action) and to political parties (which may employ rhetoric instead of action to achieve their goals). As we shall see, the Government of Lebanon's non-engagement with Israel over transboundary waters may be accurately read as 'veiled' or 'effective' consent to the established arrangement. Breaking such consent would not only be without purpose, it could also be counterproductive to the state's interest.

The contest of hegemony is conceived when consent to the hegemonic order is not total. This is the point at which resistance or counter-hegemonic tactics or processes may begin a staged journey of 'passive revolution' (see Burawoy 2003). Worth (2002) elaborates on Gramsci's understanding of the process through which one hegemonic order is actually transformed: disillusionment first leads to forces that challenge the order; struggles ensue from resistance to that challenge; compromises are made from this latter group to the new order being established, such that the new order is consolidated. Specific actions taken may be understood to occur-in Gramsci's terms-within 'wars of movement' (direct confrontation) and 'wars of position' (more subtle and strategic forms of contest designed to

${ }^{4}$ Similarly, Sosland (2007) refers to this as 'tactical functional cooperation'. See also Zeitoun et al. (2011: $168,173)$ on 'apparently 'cooperative', forms of transboundary water interaction. 
undermine the legitimacy of the order, awaken consciousness, and destabilise the consent upon which it is based (see also Worth and Kuhling 2004; Loftus and Lumsden 2007; Levy 2008)). Counter-hegemonic actions may be part of larger counter-hegemonic strategy oras in most, if not all, of the transboundary water arrangements considered later-more reactive and tactical.

\section{Theory about change: the conceptual framework of dynamic transboundary water interaction}

If we want things to stay as they are, things will have to change.

-Tancredi, character in di Lampedusa's The Leopard (1958)

This section works the review of the literature into the conceptual framework of dynamic transboundary water interaction, which is presented in the second of the following figures. It then backs the framework into a theory about change in hegemonic orders that incorporates the role of power asymmetry.

The first elements of the frame are provided in Fig. 1, which emphasises the three processes of re-enforcing, maintaining, or countering an established order. The processes of re-enforcement of the order are shown in the bottom 'compliance' oval, where the order is maintained through the full range of Lustick's compliance-producing mechanisms. These usually start with coercive mechanisms, which give way to the more effective utilitarian mechanisms. As compliance to the arrangement is more openly consented to

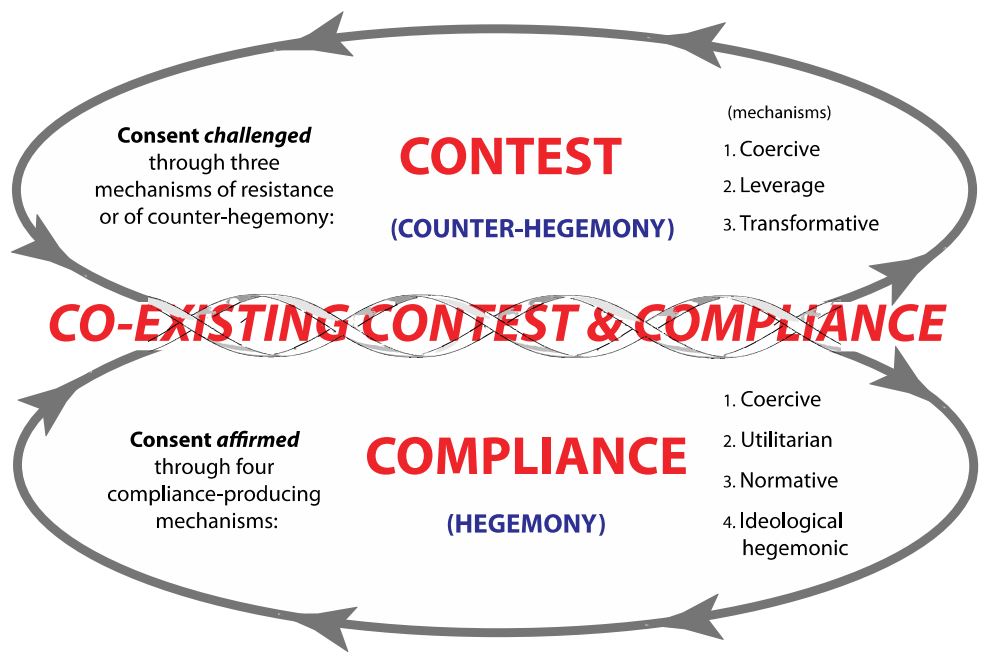

Fig. 1 A conceptual representation of contest and of compliance with a hegemonic order (not specific to transboundary water interaction). Any established order can be consented to and so re-enforced through hegemonic processes (bottom oval, clockwise), or contested and possibly transformed through counterhegemonic processes (top oval, counterclockwise). Typically, an order is maintained through a variety of processes that are classed as both compliant and contesting (between the ovals). The ranking of the mechanisms identified suggests a progression in the order of their use. Based on Cascão (2008: Fig. 1) 
(perhaps internalised), the mechanisms give way to the much more effective normative and ideological hegemonic mechanisms. ${ }^{5}$

The second process shown in Fig. 1 is collaboration, that is, the give-and-take identified by Gramsci and Cox between the hegemonic and counter-hegemonic processes. The order is understood to be maintained along these intertwined stands of the double helix by actions that may serve to reinforce or change the status quo, in what is described here as 'co-existing contest and compliance'.

It is expected that most transboundary water interaction throughout the world is shaped by these processes, including the cases of manipulative cooperation and beneficial conflict identified in Zeitoun and Mirumachi (2008) and Zeitoun et al. (2011). It is also hypothesised that counter-hegemonic movements start with strategic 'apparent' consent, within the rules set out by and within the established order, and may move on (in a 'war of positions') after awakened consciousness to counter-hegemonic tactics and possibly become a counter-hegemonic movement, most likely first through coercive or leverage mechanisms of counter-hegemony.

The focus of this paper is on the third process, that is, the 'contest' of the status quo. If any form of passive revolution is occurring, it will be evident here when consent to the transboundary water arrangement is clearly broken, and contest becomes open. The alternatives (vision, agenda, discourse, knowledge, etc.) required to undermine the legitimacy of the established order are expected to be deployed through leverage and transformative mechanisms. Each of these can be expected to initiate particular responses by the state that will provide to (or remove from) them the authority considered necessary for their perpetuation - as in Fig. 2. When enough compromises are made by actors who were re-enforcing the previous order, the new order will be consolidated, and the transformation complete. Whether the (new) form of hegemonic transboundary water arrangement resulting from the processes is more 'positive' or 'negative' than the previous one (in the sense that it increases or reduces tensions ${ }^{6}$ ) is not predetermined. ${ }^{7}$ The conceptual frame of dynamic transboundary water interaction of Fig. 2 also shows the reactions induced by hegemonic and counter-hegemonic processes, and the tactics identified for control of transboundary waters.

\subsection{The role of power in maintaining or transforming the status quo}

Withdrawing support, even symbolically, calls into question the props and illusions that hold Power up.

Gene Sharp (1975)

\footnotetext{
5 'Court jesters' reside here, alongside what Said (1978: 30) refers to as 'elaborators of thought' about dominant cultures (as opposed to independent and original thinkers). See also La Bohetie (1549): 'ce sont donc les courtisans qui se font les complices de la tyranie, perdant du même coup leur propre liberté', and Sharp (1973)—Why People Obey.

${ }^{6}$ Refer to Zeitoun et al. (2011: Table 2) for explanation of the evaluations of forms of transboundary water interaction, and see also Pak and Wegerich.

7 Warner (2007) identifies three types of response to hegemony: hegemonic challenge (competition for leadership, same rules, and ideology), counter-hegemony (contested leadership, promoting different rules and ideology, as discussed here), and breaking away from a perpetually contested cycle of hegemony and counter-hegemony-which he calls a state of 'a-hegemony', after the concept of 'asecurity'—which requires a complete transformation of the enabling systems. This is in contrast to non-hegemonic configuration, in which no state in the global or regional system has been hegemonic for a considerable time (cf Acharya 2008), but a situation of hegemony is always imminent.
} 


\section{Dynamic Transboundary Water Interaction}

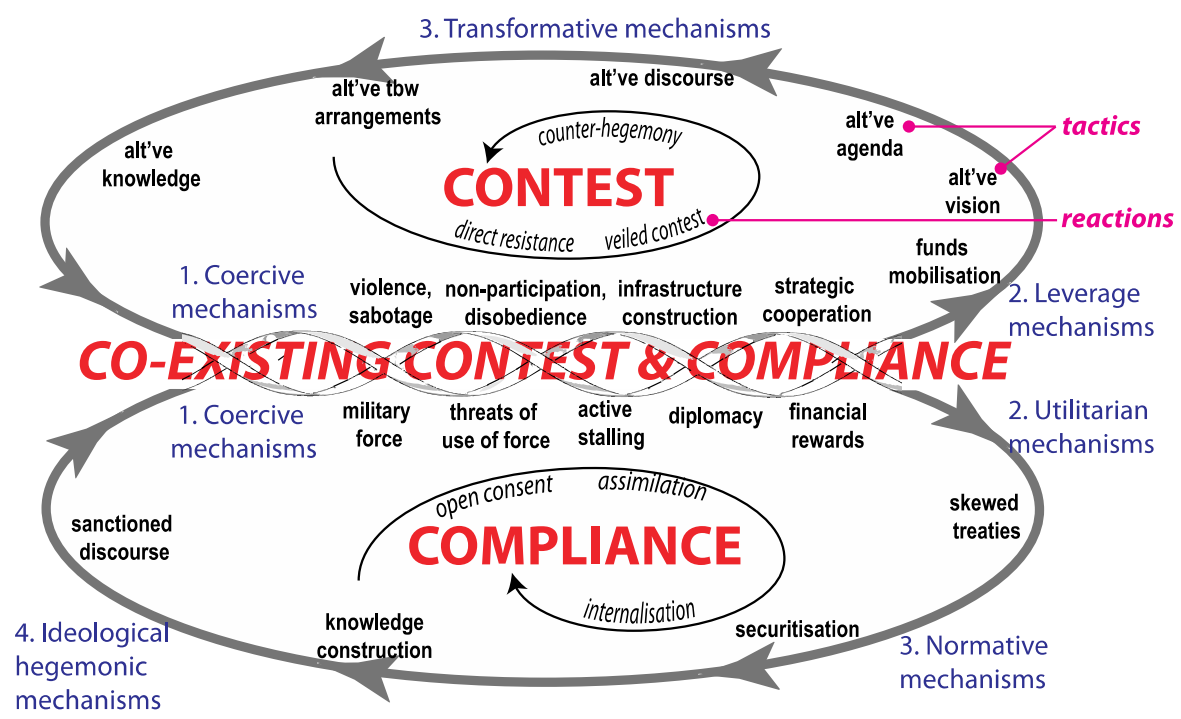

Fig. 2 A conceptual framework of dynamic transboundary water interaction-a modification of the conceptual representation of contest and of compliance with a hegemonic order of Fig. 1. The frame emphasises the reactions induced by hegemonic and counter-hegemonic processes that shape transboundary water arrangements, along with the tactics for control of transboundary waters. Based on Cascao (Cascão 2008: Fig. 1) and Zeitoun and Warner (2006)

No discussion of consent, compliance, contestation, and hegemony would be complete without careful attention to the role that power plays in the dynamic processes that maintain or transform the status quo. This paper's focus obliges attention be paid to how all dimensions of power (especially ideational power) prevents, allows, or stimulates the breaking of consent and the development of alternatives that make up a counter-hegemonic movement. It is through consent that power over ideas (even at the interstate level) blends with Gramsci's insight into the sticks and carrots used by authorities with those they rule over.

While the role that power plays in maintaining inequitable structures has been examined at the sub-national level, ${ }^{8}$ its interpretation at the international level has been limited to investigation through the prisms of negotiations and conflict resolution (see, e.g. Dinar 2000; Daoudy 2009; Dinar 2009; Kehl 2011; Brochmann 2012; Warner and Zawahri 2012). However, Zeitoun and Jägerskog (2011) have considered how various transboundary water initiatives address asymmetry - and thus might maintain or transform inequitable structures-by influencing or challenging power (Table 1).

The approach of influencing power rests on the logic of the liberal 'reform' view of change: that recognition of inequitable (or unfair) situations will lead to its rectification

\footnotetext{
8 See, e.g. D'Souza's (2002) power analysis of Indian interstate water disputes; Hamann's (2005) discussion on the challenges of confronting the status quo of well-entrenched water resource management and governance structures; (Ducrot and Barban 2008) exploration of attempts to build negotiations capacity of the weaker parties in water disputes in Saõ Paolo; Theesfeld's (2011) analysis of power plays amongst Water Users Associations and authorities in Bulgaria; and Funder et al's (2012) study of strategies developed by poor communities in Vietnam, Bolivia, and Zambia. (D’Souza 2002; Ducrot and Barban 2008).
} 
[see also Kistin (2010: Table 2.4)]. 'Speaking the truth to power', in other words, is expected to lead to altering or softening the degenerate actions of the more powerful actor. Two sub-categories have been identified under this approach: the matching of interests and the encouragement of reform. The logic of 'matching interests' rests on the assumption that powerful stakeholders will support efforts that meet their interests. Transboundary water examples include the sharing of water-related benefits (e.g. food, hydropower (e.g. Sadoff and Grey 2005; Phillips et al. 2006)) in 'win-win' and 'positive-sum outcomes' and risksharing cooperative projects (WWF-DFID 2010: 38). Initiatives in this category may be considered utilitarian compliance-producing mechanisms that result in conforming to existing power structures, in the language of Figs. 1 and 2. They do not deliberately transform the structural conditions or asymmetry in power, and so effectively maintain and re-enforce the status quo.

The reasoning of 'encouraging reform' to influence power is directly related to the leveraging mechanisms of resistance and counter-hegemony. It supposes that the interests of the weaker side may be met in part by initiatives promoted by a particularly influential person or group, and so more powerful sides may be persuaded to allow changes to existing arrangements through appeals to their leadership. The focus of such interventions remains on the hydro-hegemon, who must be persuaded (or coerced) sufficiently to act. As with the approach of 'matching interests', no challenge to the current order is claimed.

More radical and potentially transformative approaches see power asymmetry itself as a barrier to true and effective cooperation. ${ }^{9}$ The approach of challenging power seeks to directly confront power asymmetry by levelling the playing field and/or evening up the capacity of the players (Zeitoun and Jägerskog 2011). ${ }^{10}$ 'Levelling the players' involves increasing the technical or negotiations capacity, legitimacy, or authority of the less powerful side. Interestingly, the stated goal of interventions that serve in effect to level asymmetric players is rarely the contestation of hegemonic arrangements. Hydro-diplomatic programmes building capacity of formal institutions (e.g. technical and managerial expertise of the ministries of water or agriculture) are typically justified by the understanding that agreements made by relatively equal partners are more sustainable than those where they are not (see Fisher and Ury 1999).

Advocates for 'levelling the playing field' recognise that equitable arrangements can be prevented by the fact that the terms of interaction (e.g. negotiation) between the stronger and weaker parties are not balanced. Again, the reasoning is that a more even playing field will enable a more equitable (and thus sustainable) agreement. This requires careful consideration and creativity in diplomatic contexts (e.g. strengthening legislation and institutions such that all parties are subject to the same regulation) (Adelphi 2014: 20, 25). ${ }^{11}$ Transboundary water examples of this method include strengthening the application of international water and environmental law and attempts to harmonise or standardise national environmental regulation. The method deeply cuts into national issues, beyond changing interstate 'rules of the game'. It has been suggested that harmonisation of policy needs to change how water resources are used and managed across sectors within and

\footnotetext{
9 For more on the complex relationship between power asymmetry and transboundary water cooperation, see Paul (2006), Dinar et al. (2011), Adelphi (2014).

${ }^{10}$ In this sense, it is analogous to transformations of processes, or of structures (see DFID 1999: Fig. 1).

11 Formal recognition of a level playing field seems to be the key, here. See, for instance, the sub-national example of catchment management in the Sabie basin in South Africa where local stakeholders requested the endorsement from the government agency at collaborative water governance (Mirumachi and Van Wyk 2010). See also Mollinga's (2010) analysis of agricultural water reform in India.
} 
Table 1 Categorisation of the role of power with compliance or contest of a hegemonic transboundary water arrangement

\begin{tabular}{|c|c|c|c|c|}
\hline Approach $^{9}$ & \multicolumn{2}{|c|}{ Influencing Power } & \multicolumn{2}{|c|}{ Challenging Power } \\
\hline $\begin{array}{l}\text { General effect } \\
\text { on status quo }\end{array}$ & \multicolumn{2}{|c|}{$\begin{array}{c}\text { Compliance } \\
\text { (possibly reformist) }\end{array}$} & \multicolumn{2}{|c|}{$\begin{array}{c}\text { Contest } \\
\text { (potentially transformative) }\end{array}$} \\
\hline $\begin{array}{l}\text { Likely to } \\
\text { induce a } \\
\text { process of }\end{array}$ & \multicolumn{2}{|c|}{ Hegemony } & \multicolumn{2}{|c|}{ Counter-hegemony } \\
\hline Method & Matching interests & Encouraging reform & $\begin{array}{l}\text { Levelling the } \\
\text { Players }\end{array}$ & $\begin{array}{l}\text { Levelling the Playing } \\
\text { Field }\end{array}$ \\
\hline $\begin{array}{c}\text { Possible types } \\
\text { of } \\
\text { interventions }\end{array}$ & $\begin{array}{l}\text { Generation of } \\
\text { positive-sum } \\
\text { outcomes: TB } \\
\text { pollution clean-up; } \\
\text { 'joint risk' efforts; } \\
\text { hydropower } \\
\text { projects; equitable } \\
\text { water sharing; } \\
\text { benefit-sharing }\end{array}$ & $\begin{array}{c}\text { 'Naming and } \\
\text { shaming'; } \\
\text { environmental } \\
\text { diplomacy; dialogue } \\
\text { platforms (e.g. river } \\
\text { basin organisations) }\end{array}$ & $\begin{array}{l}\text { Building capacity } \\
\text { (technical, } \\
\text { negotiations, } \\
\text { administration) } \\
\text { within the } \\
\text { 'hydrocracy' or } \\
\text { ministry of foreign } \\
\text { affairs }\end{array}$ & $\begin{array}{c}\text { Objective water } \\
\text { sharing standards } \\
\text { (e.g. IWL); } \\
\text { harmonisation of } \\
\text { national } \\
\text { environmental } \\
\text { regulation }\end{array}$ \\
\hline $\begin{array}{l}\text { Associated } \\
\text { mechanism of } \\
\text { compliance, } \\
\text { resistance or } \\
\text { counter- } \\
\text { hegemony }\end{array}$ & $\begin{array}{l}\text { Utilitarian } \\
\text { compliance- } \\
\text { producing } \\
\text { mechanism }\end{array}$ & $\begin{array}{l}\text { Leveraging resistance } \\
\text { mechanism }\end{array}$ & $\begin{array}{c}\text { Transformative } \\
\text { counter-hegemonic } \\
\text { mechanism }\end{array}$ & $\begin{array}{c}\text { Leverage, or } \\
\text { Transformative } \\
\text { counter-hegemonic } \\
\text { mechanisms }\end{array}$ \\
\hline $\begin{array}{c}\text { Most relevant } \\
\text { or likely forms } \\
\text { of power } \\
\text { employed }\end{array}$ & Bargaining & Bargaining & $\begin{array}{l}\text { Bargaining, } \\
\text { ideational }\end{array}$ & $\begin{array}{l}\text { Bargaining, } \\
\text { ideational }\end{array}$ \\
\hline
\end{tabular}

In the conflict resolution terms of (Rodríguez and Correa 2006: Fig. 1), 'influencing power' may be considered a 'collaborative strategy', and 'challenging power' an 'adversarial strategy'

Examples come from typical transboundary water efforts and interventions at the state level that either influence or challenge power. Each approach is sub-classified into two methods

TB transboundary, IWL International Water Law (the 1997 UN Watercourses Convention, and the Draft Articles on Groundwater), WUA Water Users Associations. Structural determinants are not considered, for the reasons provided earlier

between states, noting the broad political economic implications that have a bearing on the way water is allocated and utilised for agriculture, industry, urban populations and other purposes (see Mirumachi 2013).

The previous examples are at the 'bargaining' level, tampering with the rules of the game, and the rules - rather than the 'spirit' — of the law. After all, implementation of international law depends entirely on the consent of state actors to be bound by it (Rieu-Clarke et al. 2012). The use of law is not expected to be as transformative as efforts that seek to fundamentally change the game itself (Farnum et al. 2016). ${ }^{12}$ Additionally, it must be noted that environmental regulation and laws can be and are often bypassed in practice, and that law itself has been used as 'hegemonic tool' (de Sousa Santos 2005: 60, see also Koskenniemi 2005). Of further note, bargaining power informs both influencing and challenging interventions (see

12 The authors convincingly argue that it is the procedural rules of International Water Law that serve to level the playing field, because the contest set up by the substantive rules is more open to power plays (see also Hawkins 2014). 
Cascão and Zeitoun 2010a), while challenge of the status quo generally requires the use of ideational power. Approaches of 'influencing power' thus deserve scrutiny for their tendency to exclude visions diverging from the established order, potentially shutting out counterhegemonic agendas for change, and so sustainable conflict resolution.

\section{Illustration of the framework}

This section presents the cases upon which the conceptual frame of dynamic transboundary water interaction was developed. An initial testing of the frame is summarised in Table 2 and discussed following.

\subsection{Static arrangements on the Jordan River and transboundary aquifers}

Along the Jordan River, we see an upstream Lebanese government (and non-state actors) vociferously asserting non-compliance with the hegemonic sharing of the flows created by Israel - many of which question the legitimacy of the existence of the state of Israel (see Amery 2000; Nasrallah 2006). The Government of Lebanon's construction of the Wazzani Pumping Station in 2002 - in the face of unofficial Israeli threats, and indirect negotiation pressure (Zeitoun et al. 2013) — can be considered a further counter-hegemonic tactic (as Westerveld (2012) claims), and possibly signals the existence of counter-hydro-hegemonic movement. The very minor Lebanese withdrawals from the river, and the extreme asymmetry in control of this upper part of the basin that has existed since 1964 (Zeitoun et al. 2013a; Wessels 2015) suggests, however, that such coercive mechanisms more accurately reflect 'veiled consent' or non-strategic resistance to the arrangement, rather than a counter-hegemonic movement.

Palestinian authorities have more openly consented to the established transboundary water arrangement, officially negotiating with Israel over the topic since 1993. There are, however, instances where the Palestinian hydrocracy has also planned many institutional and infrastructure projects in support of a completely transformed arrangement (Shikaki 1999; PWA 2011), creating conditions for a possible counter-hegemonic movement. In this light, Palestinian efforts to develop 'positive-sum' solutions to the water conflict (see PWA 2012) may be read as a negotiation tactic based on encouraging reform by the hydrohegemon. Given their declared resistance to the Israeli occupation of the West Bank and Gaza, the Palestinian negotiators may be seen to be 'strategically collaborating' through such negotiations. The official Palestinian consent to the arrangement established by Israel appears too difficult to shift for the time being, however, even with its declared parity with Israel (achieving UN-recognised 'statehood' status in 2012, despite the ongoing occupation of the West Bank and Gaza) and the effective halt of formal negotiations in 2013. Indeed, attempts to influence the hegemon have not simply failed, but backfired. As Selby (2013: 21) concludes based on his analysis of the meeting minutes of the Israeli-Palestinian Joint Water Committee: the institution has 'enabled Israel to compel the [Palestinian government] to assent to its own colonisation', through its formal approval of (and so consent to) water projects in Israeli settlements in the West Bank.

\subsection{Static arrangements on the Tigris and Euphrates}

The governments of Iraq and Syria are not currently challenging upstream Turkey's dambuilding programme (referred to as the GAP project) in any visible way, suggesting open 
Table 2 Application of the conceptual framework of dynamic transboundary water interaction to several transboundary water arrangements, from roughly 1990 to 2015. Sources: an incomplete list of documentation comes from Selby (2003), Eissa (2008), Zawahri (2008a, b), Cascão (2009a, b), Cascão and Zeitoun (2010b), Nicol and Cascão (2011), Salman (2011), Westerveld (2012), Mirumachi (2013), Selby (2013), Zeitoun et al. (2013), Çonker (2014), Menga (2014), Matthews and Geheb (2015, Mirumachi (2015) and Tawfik (2015)

\begin{tabular}{|c|c|c|c|c|c|c|c|c|c|}
\hline & & & $\begin{array}{l}\text { Jordan } \\
\text { River }\end{array}$ & $\begin{array}{c}\text { JR + } \\
\text { aquifers }\end{array}$ & $\begin{array}{l}\text { Tigris and } \\
\text { Euphrates }\end{array}$ & Ganges & Mekong & $\begin{array}{l}\text { Amu } \\
\text { Darya }\end{array}$ & Nile \\
\hline \multicolumn{3}{|c|}{$\begin{array}{r}\text { Non-hegemonic state actors } \\
\text { considered here: }\end{array}$} & Lebanon & Palestine & Iraq, Syria & Nepal & Cambodia & Tajikistan & $\begin{array}{l}\text { Ethiopia } \\
\text { (primarily) }\end{array}$ \\
\hline \multicolumn{3}{|c|}{ Degree of power asymmetry (2015): } & High & Extreme & High & Extreme & Extreme & High & Moderate \\
\hline \multirow{4}{*}{\multicolumn{2}{|c|}{ 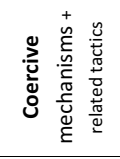 }} & Military force & $\wedge$ & $\wedge$ & $\wedge$ & $\wedge$ & $\wedge$ & $\wedge$ & $\wedge$ \\
\hline & & Threat of use of force & $* * *$ & $* * *$ & $* *$ & $\wedge$ & $\wedge$ & $*$ & $\wedge$ \\
\hline & & $\begin{array}{l}\text { Construction of } \\
\text { infrastructure }\end{array}$ & $* * *$ & $\wedge$ & $* *$ & $\wedge$ & $\wedge$ & $* * *$ & $* * *$ \\
\hline & & Financial rewards & $\wedge$ & $\wedge$ & $\wedge$ & $\wedge$ & $\wedge$ & $\wedge$ & $\wedge$ \\
\hline \multirow{3}{*}{ 品 } & \multirow{3}{*}{ 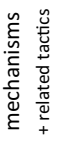 } & Strategic collaboration $^{14}$ & $\wedge$ & $\wedge$ & $* *$ & $* *$ & $* * *$ & $* * *$ & $* * *$ \\
\hline & & $\begin{array}{l}\text { Alternative } \\
\text { vision/agenda }\end{array}$ & $*$ & $* * *$ & $\wedge$ & $*$ & $*$ & $* * *$ & $* * *$ \\
\hline & & Mobilisation of funds & $\wedge$ & $\wedge$ & $\wedge$ & $*$ & * & $* * *$ & $* * *$ \\
\hline \multirow{3}{*}{\multicolumn{2}{|c|}{ 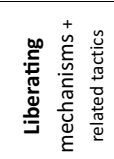 }} & Alternative discourse & $* * *$ & $*$ & * & $\wedge$ & * & $* * *$ & $* * *$ \\
\hline & & $\begin{array}{l}\text { (Establishment of) } \\
\text { Alternative tbw } \\
\text { arrangements }\end{array}$ & $\wedge$ & $\wedge$ & $\wedge$ & $\wedge$ & $*$ & $\wedge$ & $* * *$ \\
\hline & & Alternative knowledge & $\wedge$ & $\wedge$ & $\wedge$ & $\wedge$ & * & $* * *$ & $* * *$ \\
\hline
\end{tabular}

Determining whether the use of counter-hegemonic mechanisms is consciously or intentionally part of a counter-hegemonic strategy, or not, requires specific research not undertaken here. Labels of 'strategic collaboration' here in particular may be questioned

$\wedge=$ no use $; *$ mild use $; *=$ medium use $* * *=$ significant use

acquiescence, or de facto consent. Robust interpretation, however, must consider the recent past, when challenges to the arrangement were much more frequent. From the early 1980 s to the early 2000s, both governments were routinely engaged in threats to and complaints about the GAP, aligning with international anti-GAP campaigns inspired by environmental, social, or cultural concerns (Warner 2011b: Ch 2). The political and military instability that both states have since contended with means they are currently too weak to generate or deploy coercive mechanisms. Successive governments of Turkey have invoked absolute territorial (instead of shared) sovereignty over the rivers (Kramer and Kibaroglu 2011:217) and claim their management of the rivers benefits the downstream states (by regulating extremes in river flows) (Çonker 2014). The only currently viable alternatives for the downstream governments are strategic cooperation or the development of alternative discourses.

Under the Government of Turkey's 2008/2009 'zero problems with neighbours' foreign policy, a diplomatic discourse on behalf of the Government of Syria suggested Turkey and Syria had always been allied (Çonker 2014). Around that time, the Government of Iraq likewise professed to see the Ilisu Dam as a force for peace (Warner and Zawahri 2012). With construction of the Ilisu Dam under way as one of the closing pieces of the GAP on the Tigris, and Turkey concentrating its hydro-development effort in its north [on the Black Sea whose rivers are not hydraulically linked to the Euphrates-Tigris (Akpinar et al. 2011)], it could be futile for the government of Syria to attempt anything other than 'strategic cooperation' in order to at least secure some leverage in informal negotiations. With several more Iranian dams being built on the Tigris tributaries (Masih 2011), the government of Iraq has considerably more imperative to consider its counter-hegemonic options. 


\subsection{Static arrangements on the Ganges}

Successive Nepalese governments have sought to secure better opportunities to develop the Ganges River waters within a historical context where the Indian government has had the upper hand. The state-to-state discussions have currently reached deadlock, as in the case of the Mahakali Treaty. While this treaty established how Nepal and India are equal partners, the notion of 'mutual benefits' employed to derive outcomes from this partnership in river basin development has proven problematic (see Article 9 of the treaty). As Mirumachi (2015: 74-77) points out, 'mutual benefits' get bound up in issues of equality because it leaves open to interpretation how to deal existing water uses and the benefits from such. The non-water benefits of river basin development are thus also contentious, alongside the actual sharing of transboundary flows. Nonetheless, Nepali elite decisionsmakers and negotiators have accepted the sharing and appropriation of benefits, which may be read as a normative compliance-producing mechanism. To this end, 'track-two' diplomacy and other forms of dialogue amongst non-state actors have been initiated to explore options on ways to develop the river and also to engage more multilateral initiatives, contrary to the formal bilateral approaches that India has favoured in transboundary water interaction. For example, there are initiatives between the Nepali Institute of Integrated Development Studies and Indian Centre for Policy Research, along with the Bangladesh Unnayan Parishad to identify opportunities for better cooperation (see Verghese and Iyer 1993; Adhikary et al. 2000). In recent years, World Bank-funded activities under South Asian Water Initiative attempt to develop knowledge as well as networks between countries and stakeholders in multiple basins of the South Asian region (see, e.g. Sadoff et al. 2013)(World Bank 2014). An underlying challenge for sustainability is that both Nepali and Indian hydrocracies subscribe to the view of utilising the river to maximise its economic benefits (Mirumachi 2015: 71-73). The decision-makers of Nepal thus rarely table alternative visions on the way in which transboundary rivers can be governed. The high sensitivity surrounding transboundary waters also makes it difficult for alternative visions that may exist in other parts of society to be brought into discussion at the interstate level (Mirumachi 2015: 148), though recent Chinese development of the Brahmaputra River may call this into question. Thus, on the surface, the outputs in the form of joint reports and publications indicate the efforts at creating space for knowledge that may provide some new perspectives to transboundary water resources management but not necessarily to transforming the existing transboundary water arrangement. These efforts generally seek to build consensus on the importance of regional cooperation over water, however, without challenging the fundamental power relations. The efforts are thus taking the reformist approach that is not likely in the future to transform transboundary water arrangements or to resolve the transboundary water conflict.

\subsection{Shifting arrangements on the Mekong?}

Complex counter-hegemonic tactics employed by the Cambodian government on the Mekong should be read against a backdrop of a combination of the river's current hydraulic regime, ${ }^{13}$ the influence of the monsoon, and the rapid development of hydropower across the Basin. Though there are several state actors much more powerful than

\footnotetext{
13 The Mekong is a flood-pulse river with significant variations in flow from the wet to dry season. This hydraulic regime, however, is currently and will continue to undergo significant change-as upstream dams impound water during the monsoon and release more water during the dry season.
} 
Cambodia, the basin hegemon is China-also currently Cambodia's largest trading partner and close political ally. The Chinese government along with state-owned and private Chinese companies is building and/or financing dams the entire length of the river, from the Yunnan province and Lao PDR to Cambodia itself. The Thai and Vietnamese governments are also building and/or financing dams upstream of Cambodia, even as Cambodia is building dams upstream of Vietnam (Hensengerth 2015).

The Government of Cambodia government has its reasons to oppose upstream dams, particularly as it will likely have a negative impact on the ecology and hydrology of Tonlé sap, a very important source of food and livelihoods for millions of Cambodians. Yet, official or public opposition is barely perceptible. The Cambodian government has engaged in hydro-diplomacy through the Mekong River Commission and Association of Southeast Asian Nations (ASEAN) to contest upstream dam development (RFA 2012), but as neither organisation has the authority to force a government to change its policies or decisionmaking, there is little leverage possible through this diplomatic route. And while the Cambodian government does occasionally employ the media to challenge the upstream hydropower discourse to domestic audiences, as when the Water Resources Minister stated the government would oppose the construction of the Don Sahong mainstream dam (Cambodia Herald 2014), the state's downstream position, relatively limited power, and ambitions for economic growth can explain its selective use of media and diplomacy. The Cambodia government's engagement may be thus judged as strategic collaboration, further explained by calculations not to threaten benefits derived from its relationship with its ally and biggest trading partner. In effect, the political and economic costs that would come with challenging China leave few coercive mechanisms attractive to Cambodian decisionmakers. The government's own hydropower ambitions upstream of the Vietnamese Delta serve to deny it the legitimate use of liberating mechanisms such as alternative discourses and leave little deliberative space available for alternative views to be fed into the elite cadre of decision-makers. Indeed, as Hesengerth (2015) notes in his exploration of the dynamic creation of hydro-hegemony on the river, the limited influence of non-state actors can be attributed in part to their lack of authority.

\subsection{Counter-hegemony on the Amu Darya?}

The status quo has more clearly been confronted on the Amu Darya River. The government of Tajikistan's unilateral decision during the last decade to rehabilitate an abandoned Soviet-era large hydroelectric project, the Rogun Dam, is the first test of a transboundary water arrangement favouring downstream (and hegemonic) Uzbekistan (see Bekchanov et al. 2015). Adopting a series of tactics classed primarily as leveraging and liberating mechanisms, the Tajik government can be interpreted to have initiated a relatively sustained counter-hegemonic movement since 2005, with the unilateral decision to restart construction works on the Rogun Dam (BBC Monitoring 2005). These tactics include, for instance, mobilising funds and projecting an alternative vision at international water and environmental fora (see Menga 2014): through the organisation of numerous international water $_{\text {conferences }}{ }^{14}$ (in what may be called a hydro-diplomatic initiative), the Tajik government has disseminated a discourse framing large dams as benefitting the region through irrigated agriculture and generation of hydroelectric power.

\footnotetext{
14 Apart from initiating the UN to declare 2013 the 'International Year of Water Cooperation', and 2005-2015 the 'International Decade for Action Water for life', the Tajik government organises a biannual international conference on water cooperation in Dushanbe.
} 
The Rogun Dam is now one of the key issues in the basin's political discussions, and the involvement of the World Bank in the debate (particularly on issues concerning the feasibility of its construction) has increased the legitimacy of Tajik hydropower plans. This discourse jars with that put forth by the Uzbek government, which has portrayed dams as potentially catastrophic due to the risk of earthquakes. The Tajik government's position has received additional international legitimacy with the approval of the Central Asia South Asia Electricity Transmission and Trade Project, funded by the USA, the World Bank, and the Islamic Development Bank. Neighbouring Kyrgyzstan's decision to revamp the construction of the abandoned Soviet Kambarata hydroelectric project on the Syr Darya (Shalpykova 2014) is further evidence of potential transformation, or at least contest, and stands in stark contrast to the 'forced cooperation' during the Soviet era (Pak and Wegerich 2014: 241). Thus, while the Rogun Dam is yet to be completed, employing the frame demonstrates how the Tajik government has challenged the existing power asymmetry, attempting to transform the status quo in a way favouring its own hydroelectric ambitions.

\subsection{Counter-hegemony on the Nile?}

The most prominent example of contestation of a transboundary water arrangement comes from the Nile, where there has been a sizeable shift in relative power between the governments of Egypt and Ethiopia that was largely undetected as late as 2010 (see, e.g. Mekonnen 2010). The decision by Ethiopia and the Equatorial Nile states to press-on with the draft Cooperative Framework Agreement (CFA) in 2010, as well as Ethiopia's decision in 2011 to begin construction of the Grand Ethiopian Renaissance Dam (GERD), demonstrates that the hegemonic arrangement established by Egypt for so long is under threat. But is this part of an Ethiopian counter-hegemonic strategy or movement, or simply unconsidered tactics capitalising on shifts in the larger political economy? The answer will be useful to future Nile hydro-diplomatic initiatives.

The Ethiopian government's decision to build the GERD has obliged the government of Egypt to enter reluctantly into trilateral negotiations about the operation of the dam, opened the way for future dam development on the Nile (including in Sudan), and shifted the discourse of ministries and international donors from planning within the NBI to negotiating the impact of the actual development of water resources. In this sense, the dam may be seen as a liberating/transformative mechanism for Ethiopia (and a coercive one for Egypt) (Amer 2014); Tawfik (2015: 38) calls it a 'game changer'. The Ethiopian government's signature (in 2010) of the CFA may be an even greater contestation of Egypt's hydro-hegemonic arrangement. The unprecedented coalition of interests between the upstream States has resulted in a legal and institutional agreement whose effects challenge the very legitimacy of the hegemonic arrangement that was backed so completely by a number of international actors (see Ibrahim 2011). Made possible through Ethiopia's participation in the NBI, the move paved the way for construction of the GERD and the new agenda: the establishment of a permanent Nile Basin Commission and the implementation of projects identified by the NBI (including infrastructure), with or without the agreement of the two downstream riparians. The signature of the CFA has also led to a new discourse: transboundary cooperation in the Nile Basin is desirable and possible, if this legal and institutional agreement is in place (again, with or without Egypt and Sudan). If the CFA enters into force (i.e. once ratified by a sixth state), it is likely that a new reality and arrangement will emerge, one that is legitimised by the legal agreement and which may promote the 'equitable and reasonable use' principles of IWL (see Whittington et al. 2014). Regardless of interpretation, the decision clearly sets out a new agenda, discourse, 
and alternative to the established arrangement, and the era of Ethiopian consent (whether just apparent, or deeper) is over.

A counter-hegemonic reading of the situation would judge Ethiopia's participation in the NBI a form of strategic collaboration, and the emerging agendas, discourses, and arrangements as the result of leverage and transformative mechanisms aimed at challenging the power asymmetry. However, without research into the motives of the elite group of Ethiopian representatives throughout this period, it would be unfounded to suggest that this is the result of an intentional strategy of counter-hegemony. The changes could still be correctly read simply as the pursuit of state interests under changing international political economic circumstances. The tactics and mechanisms by which the transformation has occurred nonetheless suggest that a counter-hegemonic reading has at the very least shone light on previously hidden power structures. ${ }^{15}$

\section{Concluding discussion}

The summary of cases shown in Table 2 demonstrates a clear spread in transboundary water arrangements, from very little engagement at all (the 'veiled consent' of the government of Lebanon), to interaction resembling counter-hegemonic strategies (from the governments of Tajikistan and Ethiopia) — with considerable 'strategic cooperation' by the states of the cases in between. As might be expected, the most dynamic arrangements have also been witness to the full range of counter-hegemonic mechanisms, from coercive, through leveraging, to liberating. The most static arrangements have mainly seen (failed) attempts to coerce.

The influence of asymmetries in power appears associated with the degree and type of shifts in the arrangements, to an extent. For example, the power asymmetry between the basin hegemon and the less powerful states on the Jordan River explains not only the outcome of the water conflict but also the form of contestation by the non-hegemons (mainly coercive resistance resulting in nought, over the last two decades). The less powerful downstream states on the Tigris, Euphrates, and Mekong rivers appear similarly unable to shift the arrangements (through leveraging mechanisms that have been deployed), at least under the current asymmetries in power. The most dynamic arrangements are to be found in the basins where balance of power is relatively smaller, and the non-hegemonic states are upstream. The Tajik government, for example, is taking full advantage of its riparian position and of the shifts in relative state power to initiate the Rogun Dam. Recent changes along the Nile have come after a long period of Ethiopian attempts to influence power, finally confronting Egyptian hydro-hegemony in the basin through negotiations at the CFA and the building of the Grand Ethiopian Renaissance Dam. Of course each of these changes occurred within shifts in broader political contexts (the break-up of the Soviet Union, internal Egyptian instability), and so should not be overattributed to riparian position, nor the cumulative result of (probably uncoordinated) counter-hegemonic tactics like well-devised transboundary water negotiating and strategic cooperation. Likewise, on the other hand, the impact of these more local factors have some explanatory power that should not be dismissed by historical macro-explanations.

The conceptual framework of dynamic transboundary water interaction has demonstrated the limits of its utility, through the illustrations of six basins. Most compromising is its focus on the state: alternative visions of any arrangement are not expected to come from

15 Tawfik (2015) employs a benefit-sharing analysis to begin to question whether the Ethiopian counterhegemony is likely to lead to a more equitable distribution of the flows. 
government officials and thus have been passed over by this analysis. As the examples showed, Cambodian, Palestinian, Nepalese, and other state-based NGOs acting on their own or transnationally (sometimes with civil society from the hydro-hegemonic state) do challenge their own government's consent (whether apparent or veiled) or contest of a transboundary water arrangement. The frame itself does not oblige a single-minded focus on the state, however, but instead leaves space to incorporate how any number of groups may be complying with, collaborating with, or contesting an arrangement at any time. As all such groups will be influencing and influenced by their political representatives, as well as by local socioeconomic and ecological concerns and global political economic structures, their incorporation into the frame is a matter of time and effort, and there is no reason to reject the frame due to disciplinary or scalar bias.

The utility of the frame may also be compromised by the necessary simplifications it makes of very complex transboundary water arrangements. Notably, use of the frame may tend the inattentive analyst to view any action in a transboundary water arrangement as a counter-hegemonic tactic, or, even more deterministically, as part of a counterhegemonic movement or even strategy. Most such actions in the cases considered here are likely not part of a conscious counter-hegemonic strategy, but simply opportunistic outcomes of a variety of unrelated forces. Similarly, whilst the analysis has identified many counter-hegemonic mechanisms, their applicability to other cases is surely constrained by a number of factors, and unconsidered generalisation to other arrangements should be avoided.

The framework does have its merits, perhaps chiefly for identifying and offering a way of interpreting coexisting contest and compliance to critical transboundary water interaction analysis. Concerns about reading too much into any arrangement notwithstanding, the frame has thus demonstrated its ability to shine a light on previously obscured aspects of hydropolitics. It has shown, for example, why 'loud' verbal opposition to an arrangement can endure without effect for decades, or as long as it does not appear to contribute to the conception of an alternative arrangement. By focussing on processes rather than events, furthermore, the frame maintains the analysis firmly within the constantly changing broader political context. What would otherwise appear as an isolated event (e.g. a transboundary water agreement) can thus be read a part of an evolving process (a 'war of positions' in Gramsci's terms). A state's consent to any arrangement may have more to do with altering it than with aligning with it, for example. This suggests that methods reading hostile verbal announcements as 'conflict' and apparently supportive statements as 'cooperation' are poorly founded, and miss the crucial point of the power-laden structure in which the events are made.

Furthermore, the framework may serve water conflict resolution by facilitating interpretation of the dynamic relationships that characterise transboundary water arrangements. With an understanding of how arrangements change (or why they remain unchanged), hydro-diplomatic efforts can be tailored to induce movement along the pathways of change identified. In this sense, the construction of alternative visions and agendas can serve as entry and persuasion points. The agenda for further critical transboundary water interaction analysis remains packed with conceptual and empirical work, however. If it is accepted that most transboundary water processes are part of arrangements that may be most accurately labelled as 'collaboration' (i.e. the area in-between full compliance and open contest), some oscillation between the degree of compliance and contest would be expected. This may be captured conceptually in terms of a 'ratio' of contest and compliance (Mirumachi 2014).

Further work on contest and compliance would integrate neatly with the coexisting conflict and cooperation approach of the TWINS analysis, and may eventually serve as 
indicators of potential shifts in a transboundary water arrangement ${ }^{16}$ (and so spot yet more opportunities for effective hydro-diplomacy). There is also considerable work required to explore the first and second elements of the frame, and to flesh out how international political economic structures and the agency of actors interplay with each other. Much more extensive empirical work to test the frame could also serve to unearth sub- and transnational contexts, aspects of transboundary water pollution, links between compliance-producing mechanisms and types of observed compliance, biophysical peculiarities of transboundary groundwater, and the details required to begin to harmonise and group counter-hegemonic mechanisms. Finally, the role of power should be much more substantially considered, most particularly in the collaborative transboundary water arrangements between full consent and open contest.

Acknowledgments The authors would like to thank all of those who participated at the Seventh International Workshop on Hydro-Hegemony held at the University of East Anglia in London in May 2014, and in particular Mark Workman for his comments on an earlier draft.

Open Access This article is distributed under the terms of the Creative Commons Attribution 4.0 International License (http://creativecommons.org/licenses/by/4.0/), which permits unrestricted use, distribution, and reproduction in any medium, provided you give appropriate credit to the original author(s) and the source, provide a link to the Creative Commons license, and indicate if changes were made.

\section{References}

Acharya, A. (2008). Nonhegemonic international relations: A preliminary conceptualization. Working Paper No. 10-08. Bristol. School of Sociology, Politics, and International Studies, University of Bristol.

Adelphi. (2014). The rise of hydro-diplomacy: Strengthening foreign policy for transboundary waters. Climate Diplomacy Report. Berlin. Adelphi, with the German Federal Foreign Office.

Adhikary, K. D., Ahmad, Q. K., Malla, S. K., Pradhan, B. B., Rahman, K., Rangachari, R., et al. (Eds.). (2000). Cooperation on the Eastern Himalyan Rivers: Opportunities and challenges. New Delhi: Konark Publishers.

Akpinar, A., Kömürcü, I., \& Kangka, M. (2011). Development of hydropower energy in Turkey: The case of Coruh river basin. Renewable and Sustainable Energy Reviews, 15, 1201-1209.

Allan, J. A., \& Mirumachi, N. (2010). Why negotiate? Asymmetric endowments, asymmetric power and the invisible nexus of water, trade and power that brings apparent water security. In A. Earle, A. Jägerskog, \& J. Öjendal (Eds.), Transboundary water management: Policy and practice (pp. 13-26). London: Earthscan.

Amer, R. (2014). The Grand Ethiopian Renaissance Dam: A counter-hegemonic project or a start of a new hegemonic order? Presentation given at Seventh International Workshop on Hydro-Hegemony, 12/13 May 2014, London UEA Water Security Research Centre/London Water Research Group.

Amery, H. (2000). A popular theory of water diversion from Lebanon: Toward public participation for peace. In A. Wolf \& H. Amery (Eds.), Water in the Middle East: A geography of peace (pp. 121-149). Austin: University of Texas Press.

BBC Monitoring. (2005). Russia to start construction of Tajik power plant late September. Source: ITARTASS news agency, Moscow (in Russian). Number. September 19, 2005.

Bekchanov, M., Ringler, C., Bhaduri, A., \& Jeuland, M. (2015). How would the Rogun Dam affect water and energy scarcity in Central Asia? Water International, 40(5-6), 856-876.

Bieler, A., \& Morton, A. D. (2004). A critical theory route to hegemony, world order and historical change: Neo-Gramscian perspectives in international relations. Capital \& Class, 83, 85-113.

Brochmann, M. (2012). Basin asymmetries and the risk of conflict in International River Basins Chapter 4 in Bridge Over Troubled Waters: Interaction in International River.

Basins. Ph.D. Thesis. University of Oslo.

${ }^{16}$ In academic jargon, this work would essentially integrate coexisting conflict and cooperation with coexisting compliance and consent. 
Burawoy, M. (2003). For a sociological Marxism: The complementary convergence of Antonio Gramsci and Karl Polanyi. Politics \& Society, 31(2), 193-261.

Carroll, W. K. (2006). Hegemony, counter-hegemony, anti-hegemony. Keynote Address to the Annual Meeting fo the Society for Socialist Studies, York University, Toronto.

Cascão, A. E. (2007). Conceptualising counter hegemony and its application to power relations in transboundary river basins. Paper prepared for discussion prior to the Third International Workshop on Hydro-Hegemony, London School of Economics, London, UK, London Water Research Group.

Cascão, A. E. (2008). Ethiopia-challenges to Egyptian hegemony in the Nile Basin. Water Policy, 10(S2), $13-28$.

Cascão, A. E. (2009a). Political economy of water resources management and allocation in the Eastern Nile River Basin. London: Department of Geography, King's College London.

Cascão, A. E. (2009b). Changing power relations in the Nile river basin: Unilateralism vs. cooperation? Water Alternatives, 2(2), 245-268.

Cascão, A. E., \& Zeitoun, M. (2010a). Changing nature of bargaining power in the hydropolitical relations in the Nile River Basin. In A. Earle, A. Jägerskog, \& J. Öjendal (Eds.), Transboundary water management: Principles and practice (pp. 189-194). London: Earthscan.

Cascão, A. E., \& Zeitoun, M. (2010b). Tactics to counter hegemony in transboundary river basins. Presentation prepared in advance of the Fifth International Workshop on Hydro-Hegemony, London School of Economics, London, UK, London Water Research Group.

Çonker, A. (2014). An enhanced notion of power for inter-state and transnational hydropolitics: An analysis of Turkish-Syrian water relations and the Ilisu Dam. Ph.D. thesis submitted to the School of International Development. University of East Anglia.

Cox, R. W. (1983). Gramsci, hegemony and international relations: An essay in method. In R. W. Cox \& T. J. Sinclair (Eds.), Approaches to world order. Cambridge: Cambridge University Press.

Daoudy, M. (2009). Asymmetric power: Negotiating water in the Euphrates and Tigris. International Negotiation, 14(2), 361-391.

Daoudy, M. (2007). Conceptualizing and disentangling cooperation. Presentation given at the Third International Workshop on Hydro-Hegemony, 12 and 13 May 2007, London School of Economics, London, UK, London Water Research Group.

Davidson-Harden, A., Naidoo, A., \& Harden, A. (2007). The geopolitics of the water justice movement. Peace, Conflict and Development, 11, 1-34.

de Sousa Santos, B. (2005). Beyond neoliberal governance: The World Social Forum as subaltern cosmopolitan politics and legality. In B. de Sousa Santos \& C. A. Rodriguez-Garavito (Eds.), Law and globalization from below (pp. 92-117). Cambridge: Cambridge University Press.

DFID. (1999). Sustainable livelihoods guidance sheets. London: The Department for International Development.

Dinar, S. (2000). Negotiations and international relations: A framework for hydropolitics. International Negotiation, 5, 375-407.

Dinar, S. (2009). Power asymmetry and negotiations in international river basins. International Negotiation, 14(2), 329-360.

Dinar, S., Dinar, A., \& Kurukulasuriya, P. (2011). Scarcity and cooperation along international rivers: An empirical assessment of bilateral treaties1. International Studies Quarterly, 55(3), 809-833. doi:10. 1111/j.1468-2478.2011.00671.x.

Dinar, A., Katz, D., De Stefano L., \& Blankspoor, B. (2012). Climate change, conflict, and cooperation: Global analysis of the resilience of international river treaties to increased water variability. Rethinking Climate Change, Conflict, and Security Conference, University of Sussex, 18-19 October 2012.

Domènech, L., March, H., \& Saurí, D. (2013). Contesting large-scale water supply projects at both ends of the pipe in Kathmandu and Melamchi Valleys, Nepal. Geoforum, 47, 22-31. doi:10.1016/j.geoforum. 2013.02.002.

D'Souza, R. (2002). At the confluence of law and geography: Contextualising inter-state water disputes in India. Geoforum, 33, 255-269.

Ducrot, R., \& Barban, V. (2008). From revindication to proposition: Capacity building in negotiation about water management in Periurban areas. The 'Teraguas' Approach in Sao Paolo, Brazil. 13th World Water Congress, International Water Resources Association, Montpellier, September 2008.

Eissa, S. (2008). International law and hydro-hegemony in the Nile Basin: A Sudanese perspective. Water Policy, 10(S2), 29-49.

Farnum, R. L., Hawkins, S., \& Tamarin, M. (2016). Hydro-hegemons and international water law. In A. Rieu-Clarke (Ed.), Handbook on water law and policy. London: Routledge (Forthcoming). 
Fisher, R., \& Ury, W. (1999). Getting to yes: Negotiating agreement without giving in. New York: Penguin Books.

Fraser, N. (1995). From redistribution to recognition? Dilemmas of justice in a 'post-socialist' age. New Left Review, 212, 68-93.

Frey, F. W. (1993). The political context of conflict and cooperation over international river basins. Water International, 18(1), 54-68.

Funder, M., Bustamente, R., Cossio, V., Huong, P. T. M., van Koppen, B., Mweemba, C., et al. (2012). Strategies of the poorest in local water conflict and cooperation-Evidence from Vietnam, Bolivia and Zambia. Water Alternatives, 5(1), 20-36.

Gargiulo, M. (1993). Two-step leverage: Managing constraint in organizational politics. Administrative Science Quarterly, 38(1), 1-19.

Hamann, R. (2005). The power of the status quo. In J. T. Scholz \& B. Stiftel (Eds.), Adaptive governance and water conflict: New institutions for collaborative planning. Washington, DC: Resources for the Future Press.

Hawkins, S. (2014). Levelling the playing-field with international water law: Combating power asymmetries in the Israel-Palestine water conflict. M.Sc. thesis submitted to the School of International Development. University of East Anglia, Norwich.

Hensengerth, O. (2015). Where is the power? Transnational networks, authority and the dispute over the Xayaburi Dam on the Lower Mekong Mainstream. Water International, 40(5-6), 911-928.

Ibrahim, A. M. (2011). The Nile basin cooperative framework agreement in the beginning of the end of Egyptian hydro-political hegemony. Missouri Environmental Law and Policy Review, 18, 283-313.

Julien, F. (2012). Hydropolitics is what societies make of it (or why we need a constructivist approach to the geopolitics of water). International Journal of Sustainable Society, 4(1/2), 45-71.

Karriem, A. (2009). The rise and transformation of the Brazilian landless movement into a counter-hegemonic political actor: A Gramscian analysis. Geoforum, 40(3), 316-325. doi:10.1016/j.geoforum.2008. 10.005 .

Kehl, J. R. (2011). Hydropolitical complexes and asymmetrical power: Conflict, cooperation, and governance of international river systems. Journal of World-Systems Research, XVII(1), 218-235.

Kistin, E. J. (2010). Critiquing cooperation: The dynamic effects of transboundary water regimes. Department of International Development. University of Oxford, Oxford.

Koskenniemi, M. (2005). From apology to Utopia: The structure of international legal argument. Cambridge: Cambridge University Press.

Kotter, S. (1985). Power and influence: Beyond formal authority. New York: Free Press.

Kramer, A., \& Kibaroglu, A. (2011). Turkey's position towards international water law. In A. Kibaroglu, W. Scheumann, \& A. Kramer (Eds.), Turkey's water policy: National frameworks and international cooperation. Heidelberg: Springer.

La Bohetie, E. (1549). Discours de la servitude volontaire. Bordeaux: édition électronique réalisée par Claude Ovtcharenko.http://classiques.uqac.ca/classiques/la_boetie_etienne_de/discours_de_la_ servitude/discours_servitude_volontaire.pdf.

Levy, D. L. (2008). Political Contestation in Global Production Networks. Academy of Management Review, 33(4), 943-963.

Loftus, A., \& Lumsden, F. (2007). Reworking hegemony in the urban waterscape. Transactions of the Institute of British Geographers, 33, 109-126.

Lukes, S. (2005a). Power and the battle for hearts and minds. Millenium: Journal of International Studies, 33(3), 477-493.

Lukes, S. (2005 [1974]). Power: A radical view (2nd ed.). Hampshire: Palgrave MacMillan.

Lustick, I. S. (2002). Hegemony and the riddle of nationalism: The dialectics of nationalism and religion in the Middle East. Logos, 1(13 (Summer 2002)), 18-44.

Masih, I. (2011). Understanding hydrological variability for improved water management in the Semi-Arid Karkeh Basin, Iran. Delft University of Technology, Ph.D. Dissertation.

Matthews, N., \& Geheb, K. (Eds.). (2015). Hydropower development in the Mekong Region: Political, socio-economic and environmental perspectives. Routledge: London.

McCaffrey, S. (2007). The law of international watercourses. Oxford: Oxford University Press.

Mekonnen, D. Z. (2010). The Nile basin cooperative framework agreement negotiations and the adoption of a 'Water Security' paradigm: Flight into obscurity or a logical Cul-de-sac? European Journal of International Law, 21, 421-440.

Menga, F. (2014). Power and dams in Central Asia. Department of Social Sciences and Institutions. Ph.D. Thesis. University of Cagliari, Cagliari.

Mirumachi, N. (2013). Securitising shared waters: An analysis of the hydropolitical context of the Tanakpur Barrage project between Nepal and India. The Geographical Journal, 179(4), 309-319. 
Mirumachi, N. (2014). Rethinking TWINS for counter-hegemony. Presentation given at Seventh International Workshop on Hydro-Hegemony, 12/13 May 2014, London UEA Water Security Research Centre/London Water Research Group.

Mirumachi, N. (2015). Transboundary water politics in the developing world. London: Routledge.

Mirumachi, N., \& Van Wyk, E. (2010). Cooperation at different scales: Challenges for local and international water resource governance in South Africa. The Geographical Journal, 176(1), 25-38.

Molle, F. (2008). Nirvana concepts, narratives and policy models: Insights from the water sector. Water Alternatives, 1(1), 131-156.

Mollinga, P. P. (2005). The water resources policy process in India: Centralisation, polarisation and new demands on governance. Working Paper Series No. 7. Bonn. Center for Development Research, Department of Political and Cultural Change, University of Bonn.

Mollinga, P. (2010). The material conditions of a polarized discourse: Clamours and silences in critical analysis of agricultural water use in India. Journal of Agrarian Change, 10(3), 414-436.

Nasrallah, H. (2006). Hezbollah leader addresses "Victory Rally" in Lebanon. BBC Monitoring International Reports 23 September 2006, re-posted on Informed Comment blog, Juan Cole.

Newton, J. (2014). "Water, water everywhere, nor any drop to drink": An exploration of the lack of a formal global water governance regime. Ph.D. thesis submitted to the Faculty of the Fletcher School of Law and Diplomacy. Tufts University, Medford.

Nicol, A., \& Cascão, A. E. (2011). Against the flow-New power dynamics and upstream mobilisation in the Nile Basin. Review of African Political Economy, 38(128), 317-325.

Norman, E. S. (2012). Cultural politics and transboundary resource governance in the Salish Sea. Water Alternatives, 5(1), 138-160.

Pak, M., \& Wegerich, K. (2014). Competition and benefit sharing in the Ferghana Valley: Soviet negotiations on transboundary small reservoir construction. Central Asian Affairs, 1, 225-246.

Paul, T. V. (2006). Why has the India-Pakistan rivalry been so enduring? Power asymmetry and an intractable conflict. Security Studies, 15(4), 600-630. doi:10.1080/09636410601184595.

Persaud, R. B. (2001). Counter-hegemony and foreign policy: The dialectics of marginalized and global forces in Jamaica. New York: State University of New York Press.

Phillips, D., Daoudy, M., Öjendal, J., Turton, A., \& McCaffrey, S. (2006). Trans-boundary water cooperation as a tool for conflict prevention and broader benefit-sharing. Stockholm: Ministry of Foreign Affairs.

PWA. (2011). The final report. (Report 6 of the CSO-G). The Gaza Emergency Technical Assistance Programme (GETAP) on Water Supply to the Gaza Strip: Component 1-The Comparative Study of Options for an Additional Supply of Water for the Gaza Strip (CSO-G). Ramallah. Palestinian Water Authority.

PWA. (2012). The positive-sum outcome: A solution for all (brochure). Ramallah: Palestinian Water Authority.

Randall, A., \& Charlesworth, A. (Eds.). (2000). The moral economy as an argument and as a fight. New York: St Martin's Press.

Rieu-Clarke, A., Moynihan, R., \& Magsig, B.-O. (2012). UN Watercourses Convention: User's guide. IHPHELP Centre for Water Law, University of Dundee.

Rodríguez, I., \& Correa, H. D. (2006). Lessons, approaches, and challenges to transforming socio-environmental conflicts in Latin America: The "C\&C" program experience. In H. Darío Correa \& I. Rodríguez (Eds.), Environmental crossroads in Latin America: Between managing and transforming natural resource conflicts. San José: University for Peace.

Rupert, M. (1993). Alienation, capitalism, and the inter-state system: Toward a Marxian/Gramscian critique. In S. Gill (Ed.), Gramsci, historical materialism, and international relations (pp. 67-93). Cambridge: Cambridge University Press.

Sadoff, C. W., \& Grey, D. (2005). Cooperation on international rivers: A continuum for securing and sharing benefits. Water International, 30(4), 420-427.

Sadoff, C., Harshadeepa, N. R., Blackmore, D., Wuc, X., O’Donella, A., Jeland, M., et al. (2013). Ten fundamental questions for water resources development in the Ganges: Myths and realities. Water Policy, 15, 147-164.

Said, E. (1978). Orientalism. London: Routledge \& Kegan Paul.

Salman, Salman M. A. (2011). The new state of South Sudan and the hydro-politics of the Nile Basin. Water International, 36(2), 154-166.

Schmeier, S., Gerlak, A. K., \& Blumstein, S. (2015). Clearing the muddy waters of shared watercourses governance: conceptualizing international River Basin Organizations. International Environmental Agreements: Politics, Law and Economics. doi:10.1007/s10784-015-9287-4.

Scott, J. C. (1985). Everyday forms of peasant resistance. Journal of Peasant Studies, 13(2), 5-35. 
Scott, J. C. (2000). The moral economy as an argument and as a fight. In A. Randall \& A. Charlesworth (Eds.), Moral economy and popular protest: Crowds, conflict and authority (pp. 187-208). New York: St Martin's Press.

Scott, J. (2001). Power. London: Polity Press.

Selby, J. (2003). Water, power and politics in the Middle East-The other Israeli-Palestinian conflict. London: I.B. Tauris.

Selby, J. (2013). Cooperation, domination and colonisation: The Israeli-Palestinian Joint Water Committee. Water Alternatives, 6(1), 1-24.

Selby, J. (2007). Beyond hydro-hegemony: Transnational hegemonic structures and national hegemonic projects. Presentation given at the Third International Workshop on Hydro-Hegemony, 12 and 13 May 2007, London School of Economics, London, UK, London Water Research Group.

Shalpykova, G. (2014). Unmasking the face of 'Riparian Cooperation' in the Syr Darya River Basin. Ph.D. thesis. University of Nottingham.

Shamir, R. (2005). Corporate social responsibility: A case of hegemony and counter-hegemony. In B. de SousaSantos \& C. A. Rodriguez-Garavito (Eds.), Law and globalization from below (pp. 92-117). Cambridge: Cambridge University Press.

Sharp, G. (1973). The politics of nonviolent action. Boston: Porter Sargent.

Shikaki. (1999). The corridor-The geographic link between the West Bank and Gaza Strip. Ramallah, West Bank, Negotiations Affairs Department, Palestine Liberation Organisation.

Sosland, J. K. (2007). Cooperating rivals: The riparian politics of the Jordan River Basin. New York: State University of New York Press.

Stetter, S., Herschinger, E., Teichler, T., \& Albert, M. (2011). Conflicts about water: Securitizations in a global context. Cooperation and Conflict, 46, 441-459.

Suhardiman, D., Giordano, M., \& Molle, F. (2012). Scalar disconnect: The logic of transboundary water governance in the Mekong. Society and Natural Resources, 25, 572-586.

Swatuk, L. A. (2015). Water conflict and cooperation in Southern Africa. WIREs Water, doi:10.1002/wat2. 1070 .

Tawfik, R. (2015). Revisiting hydro-hegemony from a benefit-sharing perspective: The case of the grand Ethiopian Renaissance Dam. Discussion Paper 5/2015. Bonn. German Development Institute.

Theesfeld, I. (2011). Perceived power resources in situations of collective action. Water Alternatives, 4(1), 86-103.

Tilly, C. (2003). The politics of collective violence. Cambridge: Cambridge University Press.

Verghese, B. G., \& Iyer, R. R. (1993). Harnessing the Eastern Himalyan Rivers: Regional Cooperation in South Asia. New Delhi: Konark Publishers.

Wagner, R. H. (1988). Economic interdependence, bargaining power, and political influence. International Organization, 42(3), 461-483.

Warner, J. (2005). Hydro-hegemony as a layered cake: Hydro-hegemonic strategies in the case of Turkey. Presentation given at First Workshop on Hydro-Hegemony, 21/22 May 2005, King's College London, London, UK, London Water Research Group.

Warner, J. (2007). Hegemony and power. Presentation given at the Third International Workshop on HydroHegemony, May 2007, London School of Economics, London, UK, London Water Research Group.

Warner, J. (2011a). The struggle over Turkey's Illisu Dam: Domestic and international security linkages. In K. Wegerich \& J. Warner (Eds.), The politics of water: A survey. London: Routledge.

Warner, J. (2011b). Flood planning: The politics of water security. London, I.B: Tauris.

Warner, J., \& Zawahri, N. (2012). Hegemony and asymmetry: Multiple-chessboard games on transboundary rivers. International Environmental Agreements, 12, 215-229.

Wessels, I. J. (2015). Challenging hydro-hegemony: Hydro-politics and local resistance in the Golan Heights and the Palestinian territories. International Journal of Environmental Studies, . doi:10.1080/ 00207233.2015 .1041836$.

Westerveld, L. (2012). Hegemony in hot water: Who gets what, when and how? Israeli Hydro-Hegemony and Civil Society in Lebanon. M.Sc. Thesis in Political Science and International Relations. University of Amsterdam.

Whittington, D., Waterbury, J., \& Jeuland, M. (2014). The Grand Renaissance Dam and prospects for cooperation on the Eastern Nile. Water Policy, 16, 595-608.

Wolf, A. T. (Ed.). (2002). Conflict prevention and resolution in water systems. The Management of Water Series. Cheltenham: Elgar.

World Bank. (2014). Ganges strategic basin assessment: A discussion of regional opportunities and risks. Washington, D.C: International Bank for Reconstruction and Development.

Worth, O. (2002). The Janus-like character of counter-hegemony: Progressive and nationalist responses to neoliberalism. Global Society, 16(3), 297-315. 
Worth, O., \& Kuhling, C. (2004). Counter-hegemony anti-globalisation and culture in International Political Economy. Capital \& Class, 84, 31-42.

WWF-DFID. (2010). International architecture for transboundary water resources management: Policy analysis and recommendations. London. Worldwide Fund for Nature and the UK Department for International Development, with Pegasys Strategy and Development, and the UNESCO Centre for Water Law, Policy and Science.

Zawahri, N. (2008a). International rivers and national security: The Euphrates, Ganges-Brahmaputra, Indus, Tigris and Yarmouk rivers. Natural Resources Forum, 32, 280-289.

Zawahri, N. (2008b). Capturing the nature of cooperation, unstable cooperation, and conflict over International Rivers: The story of the Indus, Yarmouk, Euphrates, and Tigris Rivers. Accepted in International Journal of Global Environmental Issues.

Zeitoun, M., \& Jägerskog, A. (2011). Addressing power asymmetry: How transboundary water management may serve to reduce poverty. Report No. 29. Stockholm. Stockholm International Water Institute.

Zeitoun, M., \& Mirumachi, N. (2008). Transboundary water interaction I: Reconsidering conflict and cooperation. International Environmental Agreements, 8(4), 297-316.

Zeitoun, M., Mirumachi, N., \& Warner, J. (2011). Transboundary water interaction II: Soft power underlying conflict and cooperation. International Environmental Agreements, 11(2), 159-178.

Zeitoun, M., Eid-Sabbagh, K., Talhami, M., \& Dajani, M. (2013a). Hydro-hegemony in the Upper Jordan Waterscape: Control and use of the flows. Water Alternatives, 6(1), 86-106.

Zeitoun, M., Talhami, M., \& Eid-Sabbagh, K. (2013b). The influence of narratives on negotiations over and resolution of the upper Jordan River conflict. International Negotiation, 18(2), 293-322.

Zeitoun, M., \& Warner, J. (2006). Hydro-hegemony: A framework for analysis of transboundary water conflicts. Water Policy, 8(2006), 435-460.

Zeitoun, M., Warner, J., Mirumachi, N., Matthews, N., McLaughlin, K., Woodhouse, M., et al. (2014). Transboundary water justice: An exploration of social justice and the analysis of international transboundary water interaction. Water Policy, 165, 174-193. doi:10.2166/wp.2014.111. 